\title{
The Sawflies of Crete (Hymenoptera, Symphyta)
}

\author{
Andrew D. Liston ${ }^{1}$, Hans-Joachim Jacobs ${ }^{2}$, Marko Prous ${ }^{1,3}$ \\ 1 Senckenberg Deutsches Entomologisches Institut, Eberswalder Str. 90, 15374 Müncheberg, Germany \\ 2 Dorfstr. 41, 17495 Ranzin, Germany \\ 3 Department of Zoology, Institute of Ecology and Earth Sciences, University of Tartu, Vanemuise 46, 51014 Tartu, Estonia \\ http://zoobank.org/6CEA4772-755A-464E-B641-BE82D01160E2
}

Corresponding author: Andrew Liston (andrew.liston@senckenberg.de)

Received 16 February 2015

Accepted 21 March 2015

Published 31 March 2015

Academic editor:

Dominique Zimmermann

\section{Key Words}

Mediterranean

Tenthredinidae

taxonomy

distribution

phenology

endemism

\begin{abstract}
Forty-two sawfly species are now known from Crete, including twelve species here recorded for the first time, and excluding earlier published records of Allantus didymus (Klug, 1818) based on misidentifications. Allantus nigrolinearis (Zirngiebl, 1937) is treated as a distinct species within the laticinctus-didymus group. Aneugmenus oertzeni (Konow, 1887) is allied to the Sardo-Corsican A. bibolinii Zombori, 1979 and belongs to Aneugmenus Hartig, 1837 s. str., not Atoposelandria Enslin, 1913. Pristiphora nievesi Haris, 2002 is a new synonym of $P$. tetrica (Zaddach, 1883). Of the newly recorded species, Chevinia mediterranea Lacourt, 2003, Dolerus puncticollis Thomson, 1871 and Empria archangelskii Dovnar-Zapolskij, 1929 are simultaneously new for the country of Greece. Four species (Allantus nigrolinearis, Aneugmenus oertzeni, Periclista cretica (Schedl, 1981) and Pristiphora sp. [subbifida group]) have not been recorded outside Crete, and may be endemic. It is not clear whether the morphologically and genetically distinctive Cretan specimens of Strongylogaster multifasciata (Geoffroy, 1785) should be regarded as a Cretan endemic species, for which the name $S$. cretensis Konow, 1887 is available, or as an isolated population of $S$. multifasciata. This requires further study, as also the taxonomic status of Heterarthrus imbrosensis Schedl, 1981 (only known from Crete) and H. wuestneii (Konow, 1905) (widespread in the West Palaearctic). The sympatric occurrence of three related Pristiphora species on Acer sempervirens, two of which differ in their choice of host individuals that are at different stages of vegetative development, is remarkable. A checklist of the Symphyta of Crete is presented.
\end{abstract}

\section{Introduction}

The Greek island of Crete, in the southern Aegean Sea, is well known for its richness in endemic plant and animal species (Legakis and Kypriotakis 1994). Although the Cretan flora has been studied very intensively, much less is known about many invertebrate groups. The sawfly fauna has been treated by Schedl $(1981,1985,1993$, 2011), who based his studies mainly on material which he collected during six visits to the island, together with specimens made available by other entomologists or housed in public collections. His first paper on this topic (Schedl 1981) also collated the fragmented earlier literature containing records of Cretan sawflies. Schedl (1993) remarked on the general scarcity of Symphyta in Crete, and stated that only a total of about 150 specimens had been available to him for study. It seemed from his data, that little collecting had been done in the earlier part of spring (March and April). We accordingly chose these months for two visits to Crete in 2013. Many of the species which we encountered, represented by a total of over 600 specimens, were previously recorded in Crete only from very few individuals. For this reason we list all the material that was recently obtained.

\section{Material and methods}

A visit to Crete by Liston alone at the end of March was followed by a visit by all three authors at the end of April. 
The first visit was centered on Iraklion, with day trips mainly into central Crete. Excursions during the second visit, based at Daratsos near Chania, were mainly in western Crete and focussed on localities in and around the Lefka Ori (White Mountains). Here we paid particular attention to endemic plant species such as Zelkova abelicea: a Tertiary relict, endemic Cretan member of the Ulmaceae (Kozlowski, 2013). The two excursions allowed us to do field work at a wide range of localities spread throughout most of the island except for the most easterly part. We collected using aerial nets with extendable handles, mainly by sweeping. Most material, including vouchers of all species, is deposited in the collection of the Senckenberg Deutsches Entomologisches Institut, Müncheberg, Germany (SDEI). Additional specimens are in the private collection of H.-J. Jacobs, and some duplicates in the US National Museum, Washington DC. Results of DNA barcoding (sequencing of part of the COI mitochondrial gene) conducted as part of the Barcode of Life Project (BOLD) (Ratnasingham and Hebert 2007) are included for some taxa whose taxonomic status is discussed. The specimen codes used in BOLD are given. Numbers preceded by DEIGISHym refer to specimens deposited in the SDEI; the prefix BC ZSM HYM denotes specimens held by the Zoologische Staatssammlung, Munich, Germany. Tissue for sequencing was obtained by detaching the right-hand mid leg, or part thereof, of pinned, dried specimens. Taxonomy and nomenclature follows Taeger et al. (2010) with modifications by Liston and Prous (2014), Malm and Nyman (2015) and Prous et al. (2014).

The approximate coordinates and altitudes of the collection localities, listed alphabetically under their prefecture (from West to East), are:

Chania. Agia, $35.477^{\circ} \mathrm{N}, 23.930^{\circ} \mathrm{E}, 30 \mathrm{~m}$. Agia Irini, $35.328^{\circ} \mathrm{N}, 23.837^{\circ} \mathrm{E}, 580 \mathrm{~m}$. Askifou, $35.288^{\circ} \mathrm{N}$, $24.191^{\circ} \mathrm{E}, 690 \mathrm{~m}$. Daratsos, $35.506^{\circ} \mathrm{N}, 23.974^{\circ} \mathrm{E}, 30$ m. Drakona, $35.406^{\circ} \mathrm{N}, 24.020^{\circ} \mathrm{E}, 510 \mathrm{~m}$. Drakona 2, $35.416^{\circ} \mathrm{N}, 24.032^{\circ} \mathrm{E}, 320 \mathrm{~m}$. Fournes, $35.418^{\circ} \mathrm{N}$, $23.940^{\circ} \mathrm{E}, 200 \mathrm{~m}$. Fournes-Meskla, $35.417^{\circ} \mathrm{N}, 23.950^{\circ} \mathrm{E}$, $320 \mathrm{~m}$. Kakopetros, $35.417^{\circ} \mathrm{N}, 23.750^{\circ} \mathrm{E}, 470 \mathrm{~m}$. Kandanos, $35.333^{\circ} \mathrm{N}, 23.733^{\circ} \mathrm{E}, 420 \mathrm{~m}$. Komitades, $35.208^{\circ} \mathrm{N}, 24.173^{\circ} \mathrm{E}, 170 \mathrm{~m}$. Kournas and Georgiopolis, $35.347^{\circ} \mathrm{N}, 24.273^{\circ} \mathrm{E}, 25 \mathrm{~m}$. Lakki, $35.371^{\circ} \mathrm{N}, 23.896^{\circ} \mathrm{E}$, $900 \mathrm{~m}$. Lousakies, $35.458^{\circ} \mathrm{N}, 23.629^{\circ} \mathrm{E}, 260 \mathrm{~m}$. Meskla, $35.401^{\circ} \mathrm{N}, 23.955^{\circ} \mathrm{E}, 210 \mathrm{~m}$. Moni, $35.285^{\circ} \mathrm{N}, 23.822^{\circ} \mathrm{E}$, $110 \mathrm{~m}$. Nea Roumata, $35.383^{\circ} \mathrm{N}, 23.850^{\circ} \mathrm{E}, 410 \mathrm{~m}$. Omalos, $35.322^{\circ} \mathrm{N}, 23.913^{\circ} \mathrm{E}, 1100 \mathrm{~m}$. Omalos $2,35.325^{\circ} \mathrm{N}$, $23.891^{\circ} \mathrm{E}, 1060 \mathrm{~m}$. Platanias, $35.500^{\circ} \mathrm{N}, 23.900^{\circ} \mathrm{E}, 20$ $\mathrm{m}$. Samonas, $35.407^{\circ} \mathrm{N}, 24.108^{\circ} \mathrm{E}, 310 \mathrm{~m}$. Sempronas, $35.376^{\circ} \mathrm{N}, 23.824^{\circ} \mathrm{E}, 660 \mathrm{~m}$. Strovles, $35.369^{\circ} \mathrm{N}$, $23.670^{\circ} \mathrm{E}, 430 \mathrm{~m}$. Theriso-Drakona, $35.400^{\circ} \mathrm{N}, 23.983^{\circ} \mathrm{E}$, $600 \mathrm{~m}$. Topolia, $35.424^{\circ} \mathrm{N}, 23.687^{\circ} \mathrm{E}, 270 \mathrm{~m}$.

Rethimnon. Anogeia, $35.289^{\circ} \mathrm{N}, 24.882^{\circ} \mathrm{E}, 750 \mathrm{~m}$. Armeni, $35.295^{\circ} \mathrm{N}, 24.453^{\circ} \mathrm{E}, 400 \mathrm{~m}$. Livadia, $35.303^{\circ} \mathrm{N}$, $24.808^{\circ} \mathrm{E}, 395 \mathrm{~m}$. Moni Kato Preveli, $35.171^{\circ} \mathrm{N}$, $24.466^{\circ} \mathrm{E}, 170 \mathrm{~m}$.

Iraklion. Krasi, $35.234^{\circ} \mathrm{N}, 25.467^{\circ} \mathrm{E}, 600 \mathrm{~m}$. Marathos, $35.347^{\circ} \mathrm{N}, 24.972^{\circ} \mathrm{E}, 400 \mathrm{~m}$. Mesa Potami, $35.213^{\circ} \mathrm{N}$, $25.521^{\circ} \mathrm{E}, 720 \mathrm{~m}$. Potamies, $35.256^{\circ} \mathrm{N}, 25.387^{\circ} \mathrm{E}, 170 \mathrm{~m}$.
Lasithi. Katharo Plateau, Kopraki, $35.147^{\circ} \mathrm{N}$, $25.565^{\circ} \mathrm{E}, 1150 \mathrm{~m}$. Mesa Lasithi, $35.181^{\circ} \mathrm{N}, 25.512^{\circ} \mathrm{E}$, $820 \mathrm{~m}$. Pinakiano, $35.197^{\circ} \mathrm{N}, 25.464^{\circ} \mathrm{E}, 820 \mathrm{~m}$.

\section{Results}

Names of species not previously recorded in Crete are preceded by an asterisk $(*)$ and those for which sequences of COI barcode region of Cretan specimens are available, are indicated by a dagger $(\dagger)$. Unless otherwise stated, specimens were collected by the authors.

We found no evidence that any sawfly species uses Zelkova abelicea as a host. However, we only encountered trees and bushes of this species during two visits to Omalos, and further fieldwork at this and other sites should be undertaken.

\section{Argidae}

Arge scita (Mocsáry, 1880)

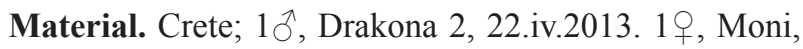

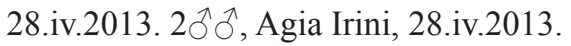

\section{Cimbicidae}

\section{Corynis krueperi (J. Stein, 1876)}

Material. Crete; $1 \delta^{\lambda}$, Potamies, 27.iii.2013, swept from inflorescences of Papaver rhoeas: a known host (Greathead 1978).

The name C. krueperi is used instead of $C$. similis (Mocsáry, 1880) for this taxon, as also in Liston and Jacobs (2012), in accordance with a revision of Corynis (Jacobs et al., in preparation).

\section{Tenthredinidae Allantinae}

\section{${ }^{\dagger}$ Allantus nigrolinearis (Zirngiebl, 1937), new status}

= Emphytus balteatus var. nigrolinearis Zirngiebl, 1937: 646; + , holotype [not examined]. Type locality: Kristallenia (Kreta) [= Panagia Kristalenia, Lasithi Plateau, East Crete]. Blank 1996; synonym of Allantus balteatus (Klug, 1818). Lacourt 1999; synonym of Emphytus laticinctus (Serville, 1823).

= Allantus didymus var. nigrolinearis (Zirngiebl, 1937); Schedl 1981; misidentification.

Material. Crete; $2 q q, 1{ }^{\lambda}$, Agia Irini, 26.iv.2013. 1q, 10ิ, Agia Irini, 28.iv.2013.

Barcode data. The barcodes of two sequenced $A$. nigrolinearis specimens (DEIGISHym20641, 20642) are identical and amongst 34 sequenced specimens of $A$. didymus and $A$. laticinctus sensu lato, are most similar to those of $A$. ariadne Liston and Jacobs, 2012 from Cyprus (DEIGISHym11089, 11093), with divergence of about $3.9 \%$. Minimal divergence 


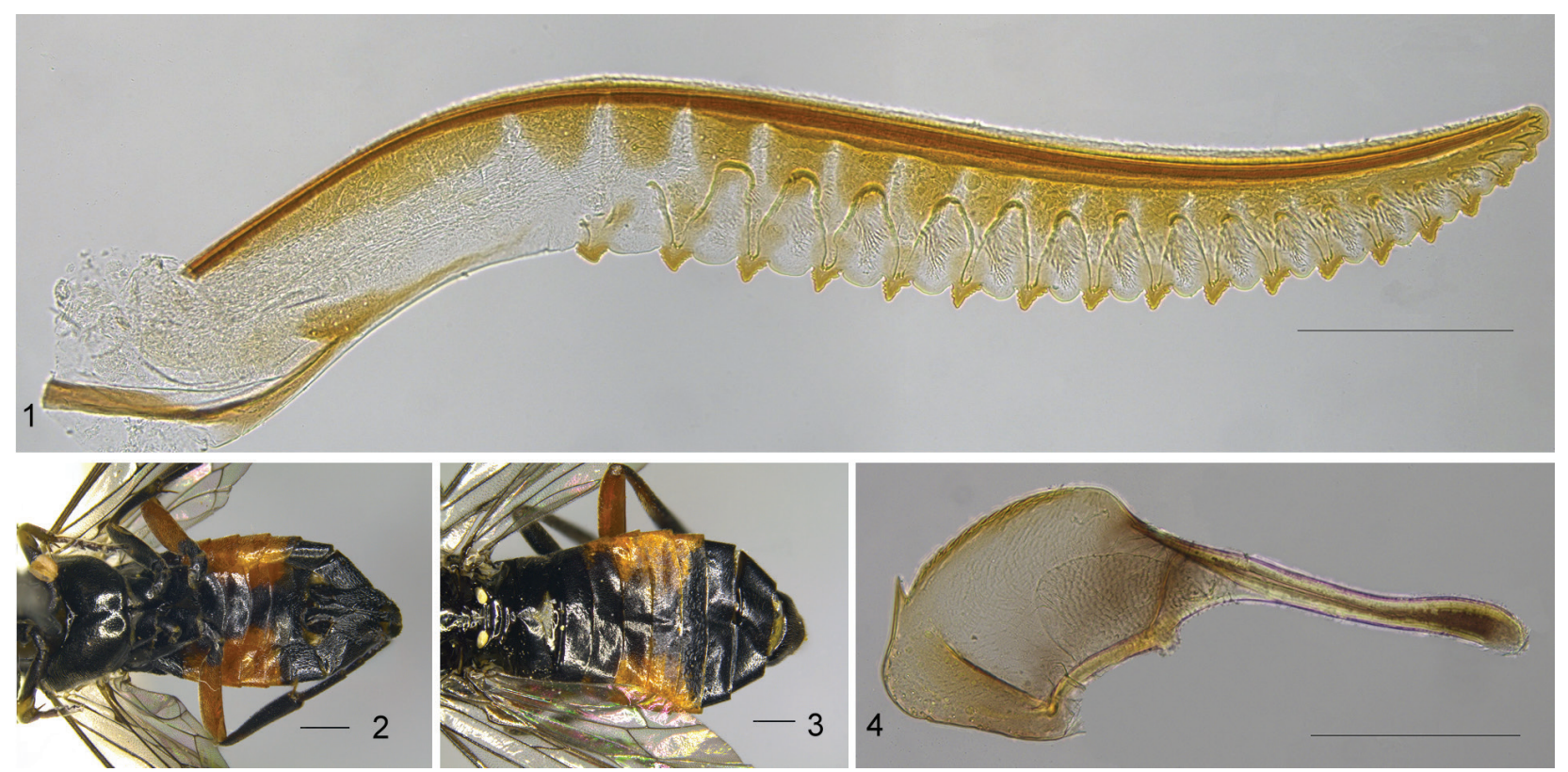

Figures 1-4. Allantus nigrolinearis, Crete. 1, lancet, $q$, scale $=0.2 \mathrm{~mm} . \mathbf{2}$, underside of abdomen,, , scale $=1 \mathrm{~mm} . \mathbf{3}$, upperside of

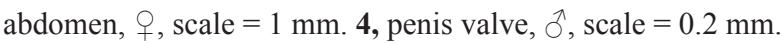

of $A$. nigrolinearis from A. laticinctus (France BC ZSM 01149 and Italy, Sicily DEIGISHym11042) is $6.4 \%$. Noteworthy is that divergence of $5.3 \%$ between $A$. nigrolinearis and A. didymus (Klug, 1818) (Italy DEIGISHym18775, and Germany; 10 specimens) is somewhat less than from $A$. laticinctus. Several other segregates cluster around the four named taxa in the barcode similarity tree, indicating that the species group requires revision and may contain more taxa than previously thought.

As noted by Blank (1996), Zirngiebl apparently had no clear concept of species, subspecies and varieties. His var. nigrolinearis was described within a paragraph discussing colour variability of a reared series of female Emphytus balteatus from Germany. However, his wording does not make it clear what relationship he considered his new variety to have to the other specimens. In the absence of any clear indication that Zirngiebl considered nigrolinearis to be of infrasubspecific rank, the name is available (ICZN 1999, Article 45.6.4.).

Female $A$. nigrolinearis differ from those of $A$. laticinctus and $A$. ariadne in having an uninterrupted, broad, median, black vitta through the otherwise red sterna of the abdomen (Fig. 2). In the other species a number of sterna are entirely red. The metatibia of $A$. nigrolinearis females is also darker: apical half, and base narrowly, fuscous. In the other species the metatibia is entirely red except for apex. In two A. nigrolinearis the otherwise red abdominal terga 3-6 have a median black stripe (Fig. 3). In the third female, this stripe is interrupted on tergum 5 and the metatibia is somewhat paler than in the other specimens. The four basal serrulae of the lancet of $A$. nigrolinearis (Fig. 1) are subtriangular and similar to the other serrulae, whereas the four basal serrulae of A. laticinctus and $A$. ariadne are more rounded than the others (Liston and Jacobs 2012, Figs 4, 6). The males of A. nigrolinearis and
A. ariadne are indistinguishable, apparently including their penis valves (A. nigrolinearis: Fig. 4. A. ariadne: Liston and Jacobs 2012, Fig. 7), but differ in leg colour from $A$. laticinctus. In $A$. nigrolinearis and $A$. ariadne the mid femur is almost entirely black except for the apex, but in A. laticinctus approximately the apical half of the mid femur is pale. The holotype of var. nigrolinearis was mistakenly considered by Schedl $(1981,1993)$ to belong to Allantus didymus (Klug, 1818) (Schedl 2011). Schedl (2011) added a record from Crete of a male specimen which he determined as $A$. didymus. However, confusion of $A$. didymus with $A$. laticinctus (sensu lato) has been widespread, particularly of the males (Koch 1988). Until more convincing evidence for the occurrence of $A$. didymus in Crete is presented, the name should be removed from the faunal list of the island.

A. laticinctus has only definitely been reared from Rosa, in central and western Europe (Taeger et al. 1998, Knight 2006). The host(s) of $A$. nigrolinearis are likely to be Rosaceae (because the known hosts of other species in this complex are Rosaceae), but as for Empria archangelskii (see below), several host species seem possible.

\section{*'Allantus viennensis (Schrank, 1781)}

Material. Crete; 1ํ, $6 \hat{\jmath}$, Daratsos, on roses (garden cultivar) in hotel garden, 21-25.iv.2013. 1ð,, Meskla, 22.iv.2013, near roses (garden cultivar). Rosa spp. are the known hosts: Taeger et al. 1998.

The garden habitat and association of the Cretan specimens with horticultural varieties of rose, suggest that $A$. viennensis may have been introduced to the island. $A$. viennensis, probably native to southern and central Europe, is also an introduced and established species in the eastern USA (Smith 2003). 


\section{${ }^{* \dagger}$ Ametastegia glabrata (Fallén, 1808)}

Material. Crete; 19, Strovles, 24.iv.2013.

One of the most cosmopolitan of sawflies, introduced to North America, South America and Australia from its (presumed) native range in the Palaearctic (Liston and Zerafa 2012).

\section{*Empria archangelskii Dovnar-Zapolskij, 1929}

Material. Crete; 1 "Ajos Joánnis Ep. Ajos Wássilis" 21.iii.1925, leg. A. Schulz, Museum für Naturkunde, Berlin. 19, Agios Nicolaos, Almyros (Lasithi), 11.iv.1976, leg. Matti Viitasaari, Viitasaari Collection, Helsinki. 19 , Mesa Potami, 28.iii.2013, swept from Crataegus monogyna. 19 , Anogeia, 29.iii.2013, swept from flowering Acer sempervirens. 1, 1ð̊, Katharo Plateau, Kopraki, 30.iii.2013, swept from low vegetation on riverbank. 1\%, Agia Irini, 26.iv.2013, swept from low vegetation on a dry slope.

Based on the serrulae of the lancet, Prous (2012) treated the Cretan specimens preliminarily as a different species (sp4) from E. archangelskii. Serrulae in Cretan specimens are narrower and more protruding (Fig. 5) than in mainland specimens (Fig. 6). Although the three studied lancets of Cretan females are very similar to each other and slightly different from the two specimens studied from the mainland (one from Crimea, and the syntype of E. archangelskii from Tuapse, Krasnodar Krai, Russia), the penis valves of males appear to be indistinguishable (Figs 9-10). Because no consistent external differences were detected between the specimens from Crete and elsewhere, and a normal variability of lancets cannot be excluded, we consider them conspecific. Selandria labialis Brullé, 1832, currently treated as a synonym of E. immersa (Klug, 1818) (Taeger et al. 2010), was described from Methoni [Plaine de Modon], Messenia, Peloponnese, an area with habitats probably similar to those in Crete. The description of $S$. labialis can be interpreted as referring to E. immersa or $E$. archangelskii, although "Chaperon très-peu échancré" [clypeus very slightly emarginate] fits better with the former. Neither of these species has otherwise been recorded from mainland Greece. The Cretan E. archangelskii are the first recorded from Greece and are the most westerly records of the species, which is otherwise known from the North coast of the Black Sea (Russia, Ukraine), Cyprus, Israel, Lebanon and Syria (Prous 2012).

The closest species to E. archangelskii is E. excisa (Thomson, 1871). E. archangelskii can be easily distinguished by the red-yellow pale colour of its legs, with femora mainly pale (black and whitish in E. excisa, with femora mainly black). There appear also to be slight differences between lancets and penis valves: serrulae are more protruding in E. archangelskii (Figs 5-6) than in E. excisa (Figs 7-8) and valviceps of penis valves might be slightly narrower and differently shaped in E. archangelskii (Figs 9-10) than in E. excisa (Figs 11-12).

The hostplant(s) of E. archangelskii are unknown. However, the larvae of Empria species which are morphologi- cally and genetically closest to E. archangelskii all feed on non-woody Rosaceae. The plants from which the specimens were collected and were growing near the collecting sites did not offer clues as to the identity of a possible host. The only Rosaceae obviously present at all Cretan collecting sites was Crataegus monogyna, but presumably the widespread Sanguisorba minor, Sarcopoterium spinosum and Rubus sanctus were also present somewhere not too distant.

\section{Athaliinae}

\section{Athalia circularis (Klug, 1815)}

Material. Crete; 1§̂, Agia, 29.iv.2013, netted from Veronica sp. growing in wet bed of a stream. Veronica spp. are known hosts (Taeger et al. 1998).

\section{${ }^{\dagger}$ Athalia cordata Serville, 1823}

Material. Crete; 1 $\lesssim$, Potamies, 27.iii.2013. $4 q q$, Mesa Potami, 28.iii.2013. 19, Krasi, 28.iii.2013. 1§̃, Daratsos, pool at hotel, 21.iv.2013. $1 \circ, 6 \hat{\jmath}$, Omalos, 21.iv.2013. 1ㅇ, Sempronas, 21.iv.2013. 1ð, Drakona, 22.iv.2013.

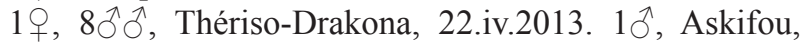
23.iv.2013. $3 \hat{\jmath} \widehat{\jmath}$, Kakopetros, 24.iv.2013. 1 ㅇ, $1 \hat{\jmath}$ Stro-

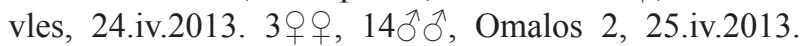

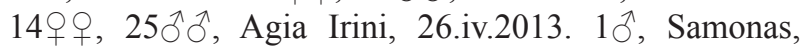

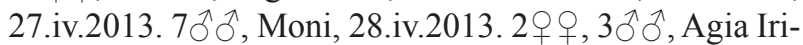
ni, 28.iv.2013. 4ふึึ̂, Agia, 29.iv.2013.

We did not collect all male specimens that were seen. During both visits to Agia Irini, males were very abundant in the uppermost part of the gorge.

\section{${ }^{\dagger}$ Athalia rosae (Linnaeus, 1758)}

Material. Crete; 1§, Strovles, 24.iv.2013.

\section{Blennocampinae}

\section{* Chevinia mediterranea Lacourt, 2003}

Material. Crete; 1, Drakona, 22.iv.2013, swept from Quercus sp. (either Q. ilex or Q. coccifera).

$C$. mediterranea was described from localities on the Mediterranean coast of mainland France and Corsica (Lacourt 2003). Specimens recorded as ? Chevinia sp. from Thessaly, mainland Greece, by Standfuss et al. (2010) also belong to this species (comparison with paratypes of $C$. mediterranea by A. Mol, S. Blank and A. Liston, 2013). The mainland specimens were also collected from Quercus spp. (K. Standfuss, personal communication), so perhaps the larval host is one or more oak species.

\section{Halidamia affinis (Fallén, 1807)}

Material. Crete; 1 , Daratsos, pool at hotel, 22.iv.2013. 1q, Meskla, 22.iv.2013.2우, Fournes-Meskla, 22.iv.2013. 

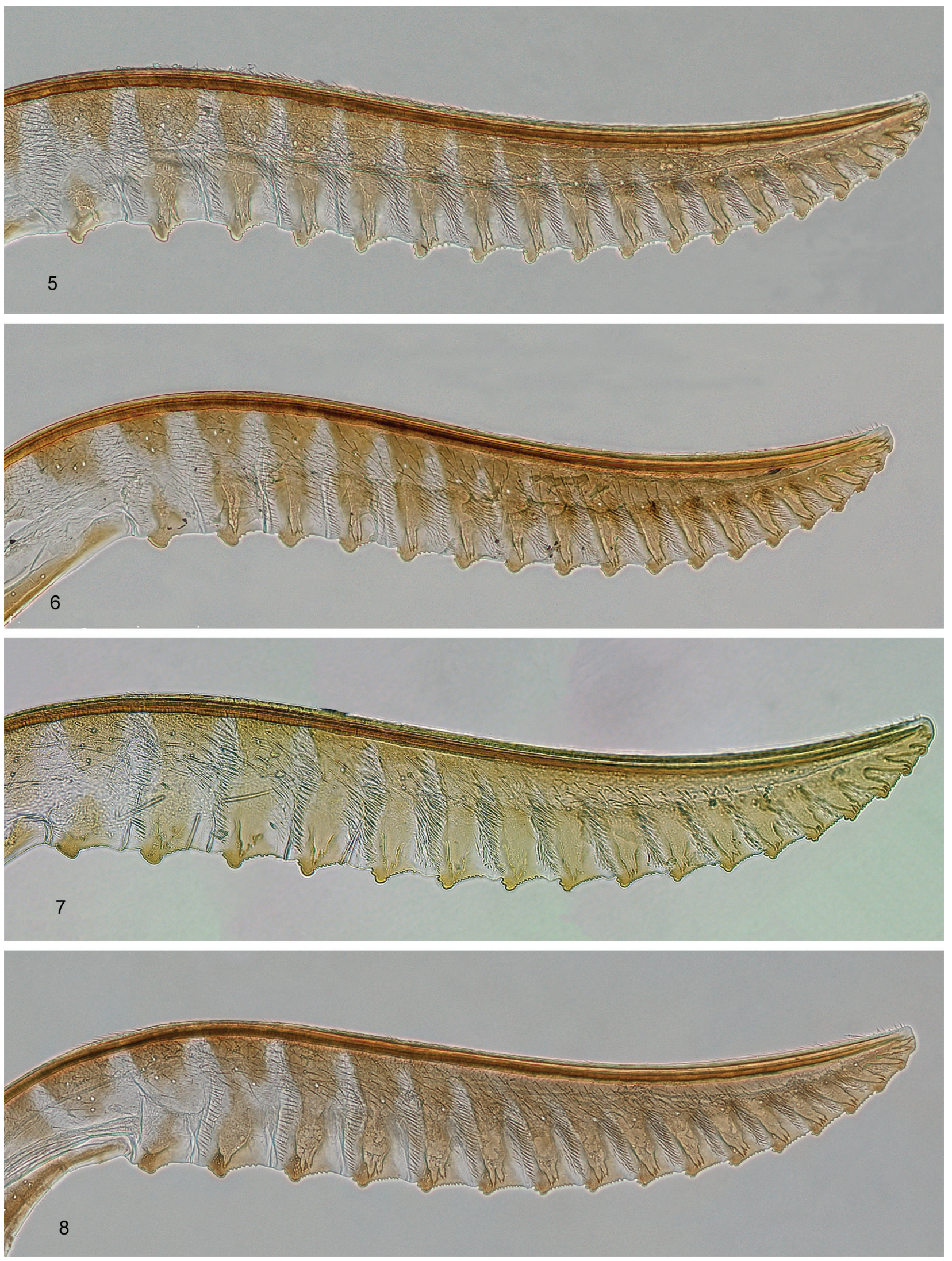

Figures 5-8. Empria, lancets, + . 5, E. archangelskii, Crete. 6, E. archangelskii, Crimea. 7, E. excisa, France. 8, E. excisa, Estonia. 

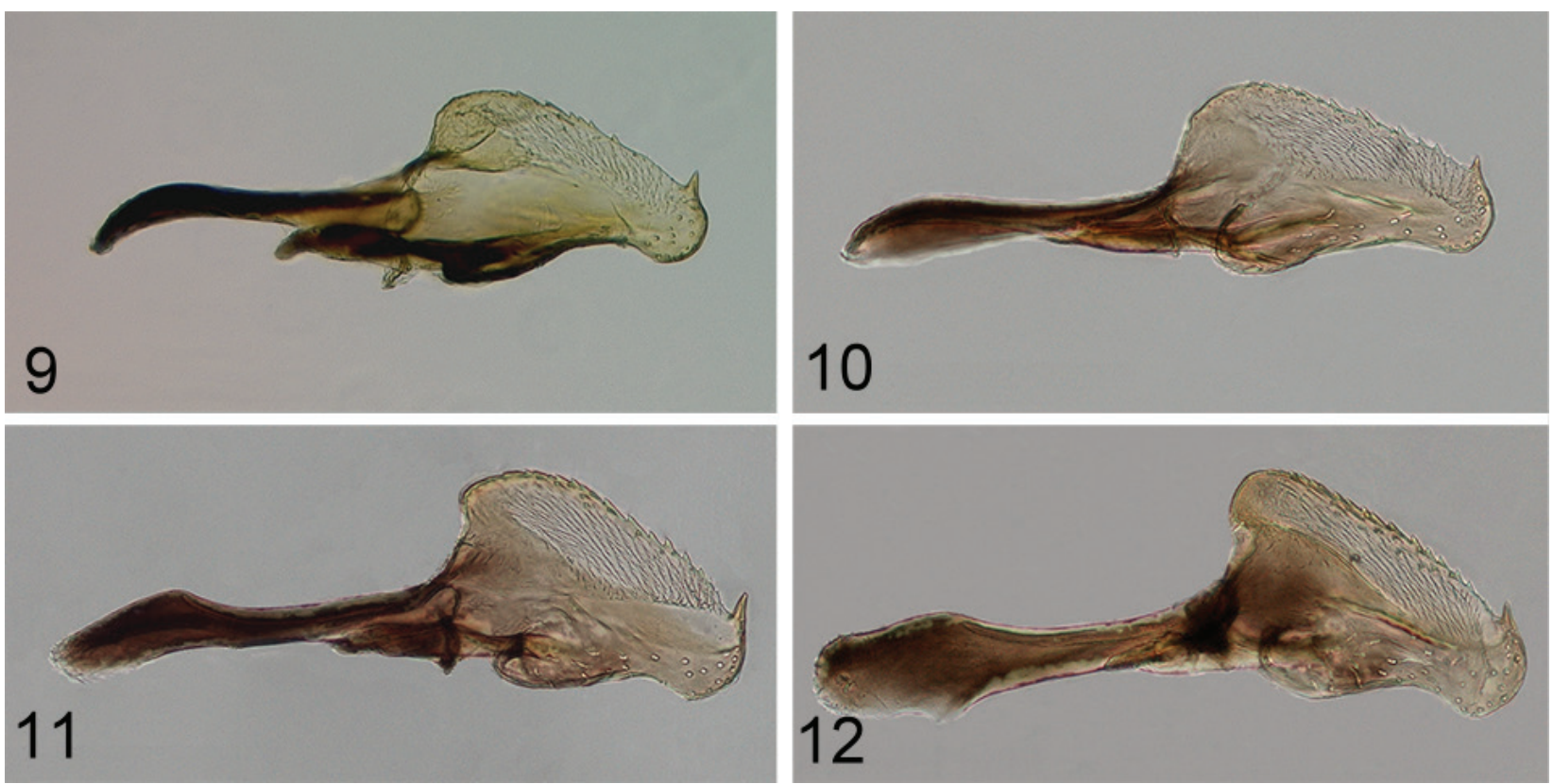

Figures 9-12. Empria, penis valves, đ̂. 9, E. archangelskii, Crete. 10, E. archangelskii, Crimea. 11, E. excisa, France. 12, E. excisa, Estonia.

1 , , Drakona, 22.iv.2013. 4 우, Agia Irini, 26.iv.2013. 1운, Samonas, 27.iv.2013. 1ㅇ, Moni, 28.iv.2013.

\section{${ }^{\dagger}$ Heterarthrus imbrosensis Schedl, 1981}

Material. Crete; 50 우, $7 \hat{\jmath}$, Omalos, 25.iv.2013, swept from Acer sempervirens: the host (Schedl 1981).

Barcode data. the barcode of one specimen collected from Acer sempervirens from the Peloponnese and determined as H. wuestneii (Konow, 1905) (DEIGISHym11102), diverges by $0.7 \%$ from two Lower Austrian specimens of $H$. wuestneii (BC ZSM HYM 04121, 04122). The minimum barcode divergence of the two barcoded Cretan H. imbrosensis (DEIGISHym20655, 20656) from the Peleponnesian $H$. wuestneii specimen is $1.8 \%$.

Morphologically. $H$. imbrosensis closely resembles $H$. wuestneii. Specimens from Crete are darker than Central European (German and Austrian) H. wuestneii. The face may be entirely black in Cretan females, but usually there are at least small white patches on the inner orbits, whilst the tegula varies from entirely black to black with the posterior edge white. The $H$. wuestneii specimens from the Peloponnese are intermediate in coloration. According to Schedl (1981), H. imbrosensis is distinguished from similar species of the aceris group by the shape of the head behind the eyes in dorsal view. No such difference was found between the specimens of $H$. wuestneii and $H$. imbrosensis available to the authors. Furthermore, the apparently apically widened sawsheath of the holotype of $H$. imbrosensis [examined] as drawn by Schedl (1981) is the result of disruption of the valves of the sheath during extraction of the saw. As pointed out by Leppänen et al. (2012), the status of some of the Acer-feeding Heterarthrus needs further study, ideally including sequencing of nuclear DNA.

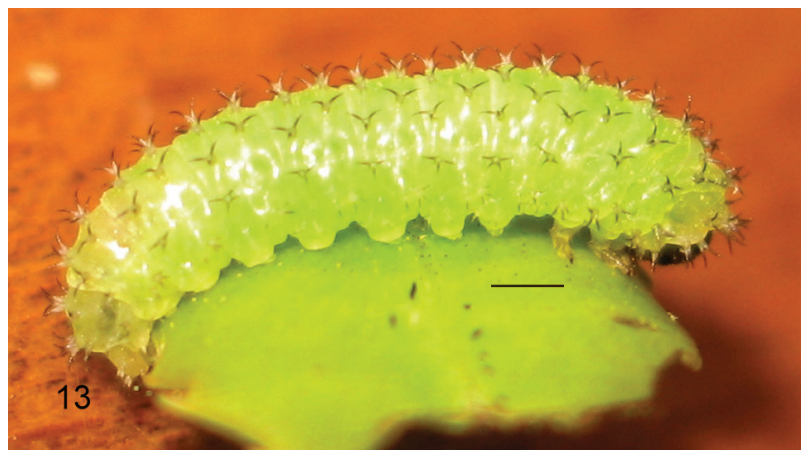

Figure 13. Periclista cretica, larva, Crete, scale $=1 \mathrm{~mm}$.

\section{${ }^{\dagger}$ Periclista cretica (Schedl, 1981)}

Material. Crete; $3 ㅇ$, 32§ð, Krasi, 27-28.iii.2013.

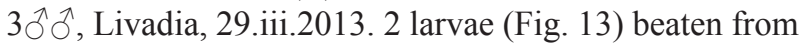
Quercus coccifera, Drakona 2, 22.iv.2013 (determined by barcode congruence of one larva with 2 adults). 19 , Askifou, 23.iv.2013. All specimens swept from, or netted near, upper branches of Quercus coccifera (plants 3-5 m tall).

The buds of the bushes and small trees of Quercus coccifera from which these were collected were swollen, but had not burst. Males were obtained mostly by netting them as they flew around the twigs in the upper crowns (at Krasi reached by standing on the many large boulders), and less so by sweeping around all accessible lower parts of the oaks. Sweeping yielded the only few females that we were able to obtain. The identification of the larvae allows us to state that $Q$. coccifera is the host plant. $P$. cretica was previously only known from the female holotype and a single male paratype (Schedl 1981), both of which we examined.

The taxonomy of this species will be dealt with in detail in a revision of West Palaearctic Periclista (A. Mol, in preparation). 


\section{Nematinae}

${ }^{*}$ Cladius ordubadensis Konow, 1892

Material. Crete; $1+$, Krasi, 28.iii.2013. 1, Agia Irini, 26.iv.2013. Swept from low vegetation containing Sanguisorba minor, which is possibly a host plant (Liston and Jacobs 2012).

\section{Cladius pectinicornis (Geoffroy, 1785)}

Material. Crete; 1ㅁ, $6 \hat{\jmath} \widehat{\partial}$, Topolia, 29.iv.2013, on Rosa sp.: the main hosts are Rosa spp. (Taeger et al. 1998).

\section{*Euura atra (Jurine, 1807)}

Material. Crete; $2 \uparrow q, 4 \hat{\jmath}$, Moni Kato Preveli, 25.iii.2013, swept from Salix alba, one of the main hosts: Taeger et al. 1998.

\section{Euura proxima (Serville, 1823)}

Material. Crete; 3 galls in leaves of Salix alba, Meskla, 22.iv.2013. Galls very abundant (hundreds) on Salix alba, Agia, 29.iv.2013.

No adults were found by sweeping foliage of the three large trees at Agia. The majority of larvae were very small when about 200 galls were collected. Nevertheless, about 30 individuals had spun cocoons by 7.v.2013. Three females emerged in June 2013. Some others seemed to have entered prolonged diapause, but no adults were reared.

\section{${ }^{\dagger}$ Hoplocampa brevis (Klug, 1818)}

Material. Crete; 1ㅇ, Marathos, 24.iii.2013. $2 \circ \propto$, Pinakiano, 27.iii.2013. 2우, Mesa Potami, 28.iii.2013. 1 우, Anogeia, 29.iii.2013. 2우, Omalos, 25.iv.2013. Specimens mostly collected from inflorescences of Pyrus cultivars: the normal hosts are Pyrus spp. (Taeger et al. 1998)

\section{${ }^{* \dagger}$ Hoplocampa chrysorrhoea (Klug, 1816)}

Material. Crete; 4우, Marathos, 24.iii.2013. $9 \circ q$, Pinakiano, 27.iii.2013. 7 웅, Mesa Potami, 28.iii.2013. 1 오, Krasi, 28.iii.2013. 10오오, Anogeia, 29.iii.2013. 1우, Omalos, 21.iv.2013. Most specimens were swept from Crataegus monogyna with unopened inflorescences, and some others from inflorescences of cultivated Pyrus growing near Crataegus.

At none of the localities were Prunus spp. seen, although these are usually considered to be the larval hosts of $H$. chrysorrhoea in northern parts of Central Europe (e.g. Taeger et al. 1998). Perhaps Crataegus monogyna is a host in Crete.
${ }^{*}$ Mesoneura opaca (Fabricius, 1804)

Material. Crete; $1 \hat{\jmath}$, roadside between Kournas and Georgiopolis, 26.iii.2013. 19, Livadia, 29.iii.2013. Both specimens swept from freshly flushed Quercus pubescens: Quercus spp. are the known hosts (Liston 2012).

The depressed medial areas of the apical abdominal terga of the male are partly pale, unlike the completely dark terga of males so far examined from mainland Greece (see Liston 2012).

\section{Pristiphora abbreviata (Hartig, 1837)}

Material. Crete; 4 larvae on cultivated Pyrus sp., Fournes, 25.iv.2013. One larva, larger than the others, had spun a cocoon by 7.v.2013.

\section{${ }^{\dagger}$ Pristiphora cretica Schedl, 1981}

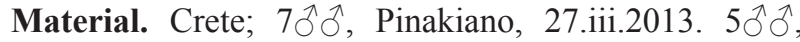

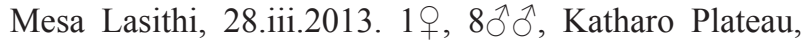

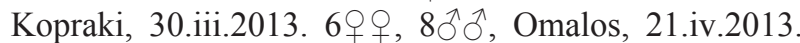

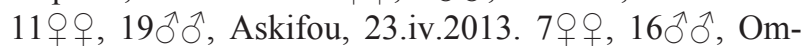
alos, 25.iv.2013. 2 우, Agia Irini, 26.iv.2013. All specimens swept from Acer sempervirens: because all species of the Pristiphora subbifida group use Acer spp. as hosts (Liston and Späth 2008), A. sempervirens (the only Acer sp. occurring in Crete) is probably a host.

Barcode data. Minimum divergence of three Cretan P. cretica (DEIGISHym20657-20659) from two northern Greek P. cretica (DEIGISHym11052, 19646) is approximately $1.2 \%$. Interspecific divergence from the next nearest species, P. schedli (Cyprus: DEIGISHym10980, 10981 ) is about $3.8 \%$.

In Crete Acer sempervirens displays considerable infraspecific variability in the timing of bud burst. Although Pristiphora cretica occurred at some localities together with $P$. tetrica (Zaddach, 1883), it was observed that these species have strongly differing preferences for trees at different stages of leaf and flower development. $P$. cretica is found exclusively on trees whose buds have fully opened and which are already flowering, whereas $P$. tetrica is found on trees whose buds have not yet burst, or have just opened. The preference is so strong, that this phenomenon could be observed on trees standing beside each other which were at different stages of flushing (Fig. 14). The difference in habit is also reflected in the temporal distribution of collection data: a larger number of $P$. cretica and higher proportion of females were recorded during the second 2013 visit than during the first, whereas most specimens of $P$. tetrica were collected during the first visit.

The Cretan specimens listed above closely resemble the female holotype and male paratype (examined: Liston and Späth 2008), the only specimens previously known from Crete. Variability in the newly collected specimens affects the extent of pale coloration on the 


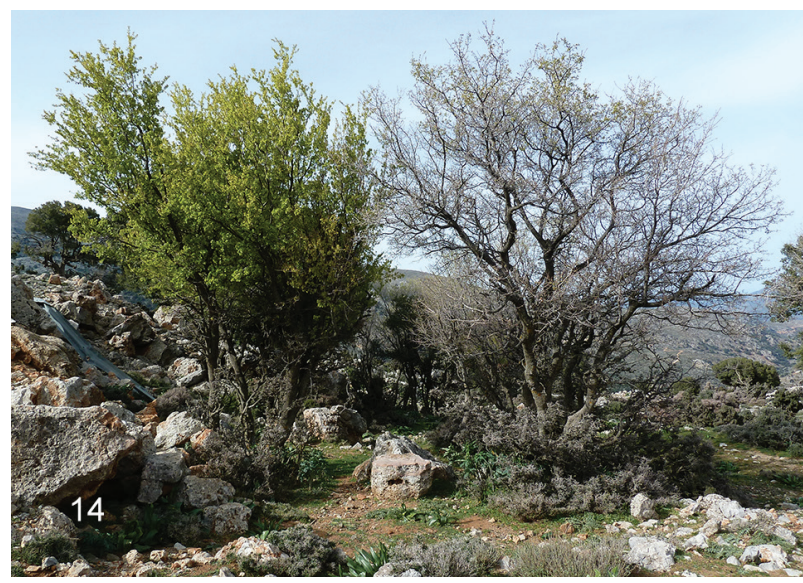

Figure 14. Acer sempervirens at different stages of bud-break. On the tree at left only Pristiphora cretica adults were found and on tree at right only P. tetrica. Crete, Lasithi Pref., Pinakiano, late March 2013

pronotum, outer orbits, clypeus and labrum in both sexes, and the extent of pale colour on the abdominal sternites. Specimens from the Vikos area, northern Greece $(1$ ㅇ, $7 \hat{\jmath} \hat{\jmath}$, Nom. Ioannina, Aristi, 16.4.2008, leg. Liston, SDEI) are very dark, with pronotum, abdominal sterna and metafemora nearly completely black. In a series ( $3+\circ$ ㅇ, $3 \precsim \widehat{\jmath}$; SDEI) collected by S. M. Blank and C. Kutzscher in the western Peloponnese, the females are much paler than either the Cretan or Vikos specimens: abdomen including terga almost completely pale, in some specimens central part of mesepisternum pale. Colour of the Peleponnesian males falls within the range of variability seen in Cretan specimens. Some of the paler individuals of $P$. cretica could be mistaken for $P$. tetrica (Zaddach, 1883). Specimens of these species from the Mediterranean Region can be distinguished as follows:

- Metafemur at least with black stripes on anterior and posterior edges of dorsal face. Female with clypeus and labrum pale marked; male with at least labrum pale (brown). Abdominal terga largely black, rarely yellow (Peloponnesian $q$ ) and if so then tergum 1 also largely yellow. Female length 5-6 mm; male 4-5 $\mathrm{mm}$.

P. cretica

- Metafemur entirely yellow, except for black area on extreme base. Clypeus and labrum entirely black. Abdominal tergum 1 black; other terga yellow, except at most for small medial flecks on terga $2-3$. Female length $4.0-4.5 \mathrm{~mm}$; male $3.5-4.0 \mathrm{~mm}$..........P. tetrica

\section{*Pristiphora pallidiventris (Fallén, 1808)}

Material. Crete; 1 , , Daratsos, pool at hotel, 21.iv.2013. 1 , , Theriso-Drakona, 22.iv.2013.

These specimens are of the colour form with a very pale abdomen, which has sometimes been treated as a separate species, $P$. denudata Konow, 1902.

\section{Pristiphora parnasia Konow, 1902}

Material. Crete; 1ㅇ, Krasi, 27.iii.2013. 1으, Livadia, 29.iii.2013. Both specimens swept from Quercus coccifera.

\section{${ }^{\dagger}$ Pristiphora sp. [subbifida group]}

Material. Crete; 1§, Omalos, 21.iv.2013. Swept from Acer sempervirens, which is probably a host plant, because this is the only Acer sp. occurring in Crete and all species of the Pristiphora subbifida group use Acer spp. as hosts (Liston and Späth 2008).

Barcode data: the sequence of this specimen (DEIGISHym20661) diverges by about $4.8 \%$ from its nearest neighbour, P. tetrica (Zaddach, 1883) from Sicily (DEIGISHym10972). Divergence from two Cretan P. tetrica (see below) is approximately $5.3 \%$ and from $P$. schedli Liston and Späth, 2008 (Cyprus) approx. 8.6\%.

Externally, the specimen differs from Cretan Pristiphora tetrica males only in the apex of the metatibia and most of metabasitarsomere being pale: Fig. 15 (largely black in P. tetrica: Fig. 19) and its slightly larger body length of $4.5 \mathrm{~mm}$ (P. tetrica: $3.5-4.0 \mathrm{~mm}$ ). However, the penis valve of the unidentified species (Fig. 16) differs substantially from $P$. tetrica (Fig. 17), and resembles that of $P$. schedli: valvispina medially thickened and not strongly upcurved (in other subbifida group species not medially thickened, but strongly upcurved), apex of paravalva at base of valvispina not strongly expanded (other species: strongly expanded). On the other hand, the coloration of the head and thorax is much darker in Pristiphora sp. than in $P$. schedli, while the legs of the former are paler. Despite its morphological similarity to P. schedli, the very large barcode divergence of the single Cretan specimen suggests that it probably represents a previously unrecognized species. Possibly one of the two unidentified female Pristiphora specimens mentioned by Schedl (2011) belongs here. Further material should be obtained so that its status can be evaluated.

\section{${ }^{*}$ Pristiphora tetrica (Zaddach, 1883)}

= Nematus tetricus Zaddach in Brischke, 1883: 148-149;

, holotype. Type locality: Gumperda, Thüringen.

Type probably destroyed (Liston and Späth 2008).

= Nematus velatus Zaddach in Brischke, 1883: 149; 우, holotype. Type locality: Baiern [Bavaria]. Type should be in the Zoologische Staatssammlung, Munich, but was not located (Liston and Späth 2008).

= Pristiphora tetrica: Lacourt 1976, description of male.

= Pristiphora nievesi Haris, 2004: 164-165; + , holotype and paratypes [Museo Nacional de Ciencias Naturales, Madrid; examined]. Type locality: El Ventorillo, Madrid. New synonym.

Material. Crete; 7우, 3ठึ, Pinakiano, 27.iii.2013.

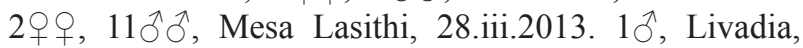



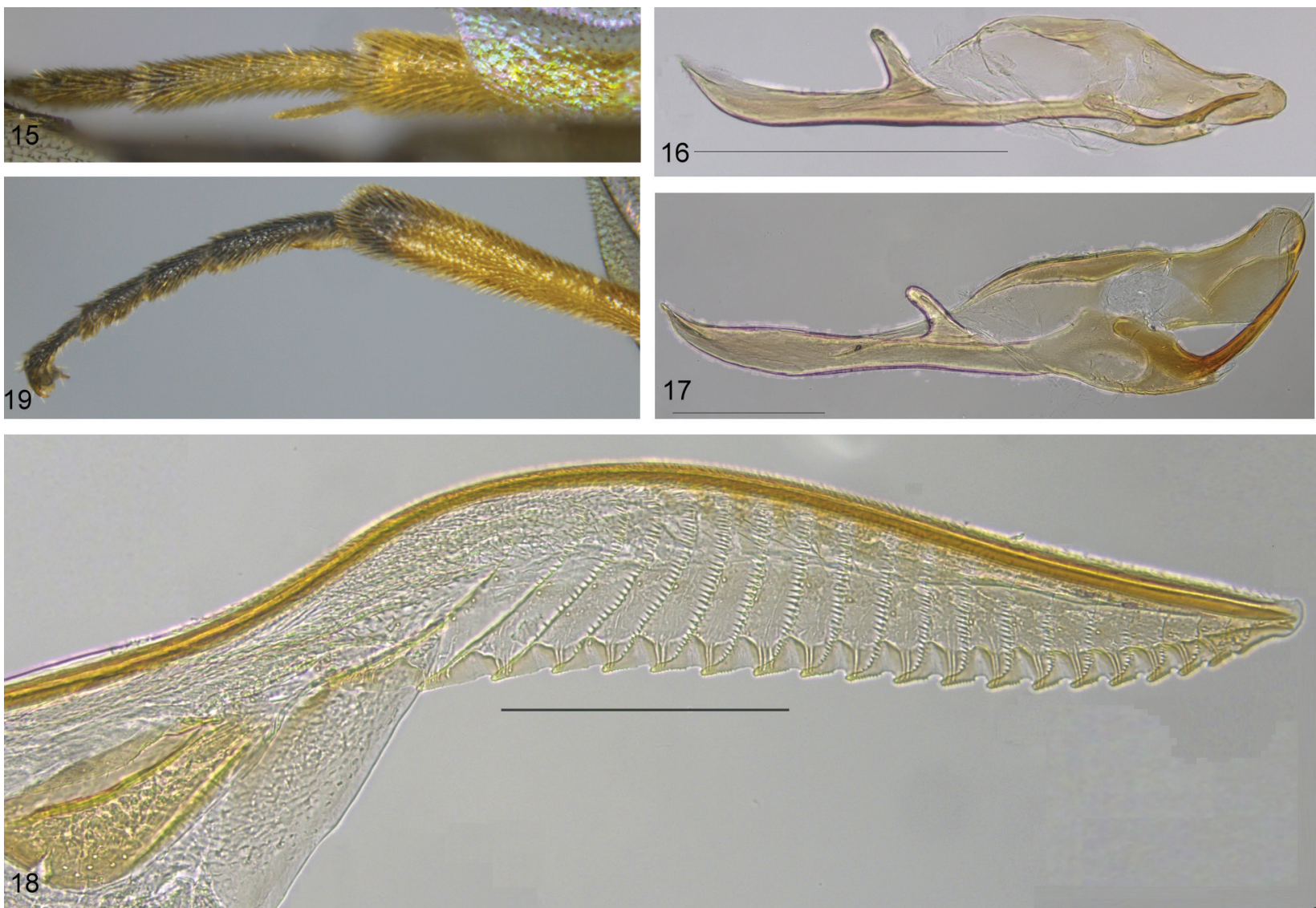

Figures 15-19. 15-16. Pristiphora [subbifida group], Crete, ô. 15, apex of metatibia and part of tarsus. 16, penis valve, scale $=0.5$ mm. 17-19. Pristiphora tetrica, Crete. 17, penis valve, $\hat{O}$, scale $=0.2 \mathrm{~mm} . \mathbf{1 8}$, lancet,, , scale $=0.2 \mathrm{~mm} . \mathbf{1 9}$, metatarsus and apex of metatibia, $\widehat{c}$.

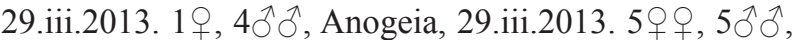
Katharo Plateau, Kopraki, 30.iii.2013. 1우, 10, Omalos, 21.iv.2013. 2o+ , Omalos, 25.iv.2013. All specimens swept from Acer sempervirens: because all species of the Pristiphora subbifida group use Acer spp. as hosts (Liston and Späth 2008), A. sempervirens (the only Acer sp. occurring in Crete) is probably a host.

Barcode data: sequences have been obtained for five specimens that were previously identified as $P$. nievesi: one specimen each from France, DEIGISHym19640; Italy, Sicily, DEIGISHym10972; mainland Greece, DEIGISHym10965, and two from Crete (DEIGISHym20660, 20662). Nested within this cluster in the barcode similarity tree are three specimens of $P$. tetrica from Germany (BC ZSM HYM 09418, BC ZSM HYM 20222, DEIGISHym18864). Although the minimum sequence divergence of the Cretan specimens from the German ones is about $1.9 \%$, the Sicilian specimen differed from the German ones by only $0.6 \%$. This is a comparatively small barcode difference (Hebert et al. 2004).

$P$. tetrica and $P$. nievesi have been recognized as being morphologically the most similar Pristiphora species within the Pristiphora subbifida group (Haris 2004, Liston and Späth 2008); even the penis valves and lancets (Cretan specimens: Figs 17, 18) are indistinguishable. However, the phenotypes do display minor differences in colour and size:
- At least metafemur mainly yellow. Abdomen predominantly yellow; black are only tergum 1 and at most small medial flecks on terga $2-3$. Wing membrane subhyaline. Female length 4.0-4.5 mm; male 3.5-4.0 $\mathrm{mm}$. P. nievesi

- Hind legs completely black. Abdomen usually with numerous terga medially and contiguously black. Wing membrane fuscous. Female length $5.0-6.5 \mathrm{~mm}$; male $4.0-5.0 \mathrm{~mm}$.....

P. tetrica

Note. Occasional Central European specimens of $P$. tetrica occur that are unusually pale. They are larger than the types of $P$. nievesi but similarly coloured, apart from having black metafemora. One such individual is the type of Nematus velatus, described as having an almost completely yellow abdomen and less fuscous wings than typical $P$. tetrica. Specimens formerly identified as $P$. nievesi differ from each other in the colour pattern of the legs. The metatibia of the type specimens and the French specimen (Savina et al. 2014) is extensively or completely black. The base of the metatibia of the Sicilian and northern Greek specimens is obscurely paler. The Cretan specimens are paler than all of these, with the metatibia only apically black. For the following reasons, it seems best to regard the southern European $P$. nievesi as merely a series of relict populations of $P$. 
tetrica, and to treat them all as conspecific: a continuous gradient of variability in colour and size occurs between Central European $P$. tetrica specimens and specimens which have recently been treated as $P$. nievesi; morphology of lancets and penis valves is identical; genetic data at present reveals no clear difference between these nominal species.

See comments on phenology and distinction of $P$. tetrica from $P$. cretica, under $P$. cretica (above). Colour variability in $P$. tetrica from Crete is in the extent of pale on the outer orbits, tegulae and posterior edges of the pronotum. These parts are usually partly pale, but are entirely black in the darkest individuals. Males tend to be darker than females. Occasionally in females, the mesepisternum is partly pale medially.

\section{Selandriinae}

\section{${ }^{\dagger}$ Aneugmenus oertzeni (Konow, 1887)}

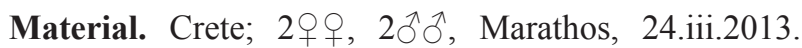

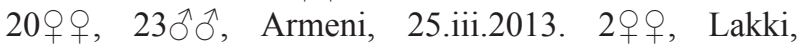
21.iv.2013. 7우우, 19ðð, Sempronas, 21.iv.2013. 2 우우, $5 \hat{\jmath}$, Drakona, 22.iv.2013. $5 \phi q, 4 \hat{\jmath} \widehat{\jmath}$, Theriso-Drako-

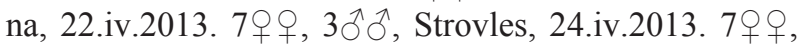

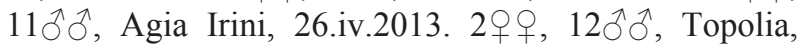

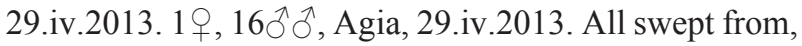
or netted near, Pteridium aquilinum, the only known host (Schedl 2011).

Barcode data. The barcodes of four sequenced Cretan specimens (DEIGISHym20637-206340: infraspecific variability about $0.7 \%$ ) diverge by a minimum of $6.1 \%$ from the nearest neighbour A. bibolinii Zombori, 1979, represented by one male each from Corsica (first record from France: Ascu, 02.05.2004, leg. Liston, SDEI (DEIGISHym19725) and Sardinia (DEIGISHym19684): infraspecific variability about $0.7 \%$. Minimum divergence of $A$. oertzeni to the next nearest species $A$. padi is $9.2 \%$ (many specimens from central and southern Europe, and Iran).

According to Benson (1968), A. oertzeni occurs not just in Crete (its type locality), but also in "Turkey and S. E. Europe". However, in the same publication Benson stated that he had never seen specimens of this species. His statement may have been influenced by Konow (1905), who gave the distribution as Crete, Asia Minor and Moscow. The occurrence of $A$. oertzeni outside Crete has not been confirmed.

Niu and Wei (2013) placed Aneugmenus oertzeni in Atoposelandria (type species Selandria fuerstenbergensis Konow, 1885), which they treated as a genus distinct from Aneugmenus (type species Tenthredo coronata Klug, 1818). A. fuerstenbergensis is indeed distinguished from the other West Palaearctic Aneugmenus species by several characters: see for example key by Blank (1998). Niu and Wei (2013) stated that "Atoposelandria differs from Aneugmenus in the clypeus roundly and deeply incised; the frontal wall very sharp; claw slender and weakly bent, without basal lobe, and the inner tooth ab- sent". The depth and shape of the excision of the clypeus is by no means so different between A. fuerstenbergensis and other Aneugmenus as they suggest, and the development of the frontal wall shows considerable differences between the other W. Palaearctic species. On the other hand, A. fuerstenbergensis is unique amongst West Palaearctic species in the claws lacking an inner tooth, the densely transversely striated and matt abdominal terga and the lack of a sinus sexualis in the male. Nevertheless, at present there are no compelling arguments for the recognition of a separate genus, because insufficient phylogenetic evidence is available to support this, and because the practical value of the distinction is low: apart from $A$. fuerstenbergensis and $A$. oertzeni, Niu and Wei (2013) place only two other species, from the Oriental Region, in Atoposelandria. For the present, we point out that according to Niu and Wei's definition of Atoposelandria, A. oertzeni does not belong there, but shares the "generic" characters of other W. Palaearctic Aneugmenus. In particular, its claw has an inner tooth, at least half as long as the outer. The inner one is however easy to overlook, as in all Aneugmenus species, because it arises close to the base of the claw and is obscured by setae and other parts of the apical tarsomere. Schedl (1981), who examined the types of Selandria oertzeni in the SDEI observed that $A$. oertzeni resembles $A$. coronatus (Klug, 1818). This is closer to reality than the comments of Benson (1968), who wrote of A. oertzeni: "This species, which I have never seen, is distinguished from $A$. padi by its untoothed tarsal claws. From $A$. fuerstenbergensis it is distinguished in the $\hat{\sigma}$ by having the 6th tergite emarginate apically and a transverse groove (sinus sexualis) across the 7 th tergite (as in A. padi) and the tergites yellow from the 3 rd segment; and in both sexes by the shining surface of the tergites which in $A$. fuerstenbergensis are dull with transverse striations." On reading the original description of $S$. oertzeni, one sees how Benson was misled. Konow (1887) wrongly stated that oertzeni has simple claws and accordingly compared the taxon with the only other West Palaearctic Aneugmenus species that does have simple claws, namely $A$. fuerstenbergensis. Our examination of the types of $A$. oertzeni and the recently collected specimens revealed that this species is morphologically similar to A. padi. Externally, they can only be distinguished by colour characters and the larger inner tooth of the claw of $A$. padi. However, barcoding suggests a closer relationship of $A$. oertzeni to A. bibolinii than to A. padi. A revised key to West Palaearctic Aneugmenus species is in preparation.

\section{*Dolerus puncticollis Thomson, 1871}

Material. Crete; 1q, Katharo Plateau, Kopraki, 30.iii.2013.

As well as being the first record of a Dolerus species from Crete, this also seems to be the first published re- 
cord of D. puncticollis from Greece. This is the most widespread Dolerus (Poodolerus) species in the Mediterranean Region, and the only member of the subgenus known in North Africa (Lacourt 1977).

\section{†Strongylogaster multifasciata (Geoffroy, 1785)}

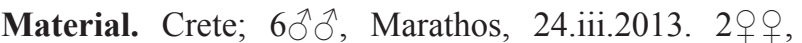

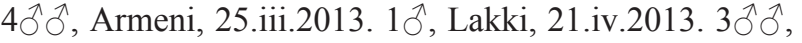
1 으, Sempronas, 21.iv.2013. 1 ,, $13 \hat{\jmath} \widehat{\jmath}$, Thériso-Drakona, 22.iv.2013. 2qㅇ, 3ठิす, Drakona, 22.iv.2013. $9 ㅇ ㅜ, 6 \hat{\jmath}$, Strovles, 24.iv.2013. $3 ㅇ+q, 2 \hat{\jmath}$, Agia Irini, 26.iv.2013. 3 우, $2 \hat{\jmath}$, Agia Irini, 28.iv.2013. 1ڤ̂, Topolia, 29.iv.2013. 1§̂, Agia, 29.iv.2013. All swept from, or netted near Pteridium aquilinum, which is the only known host in Crete: Schedl 1981, 1993, 2011.

Barcode data. The barcodes of three sequenced Cretan specimens (DEIGISHym20648-20650) are identical and diverge by a minimum of $3.2 \%$ from 24 specimens of S. multifasciata collected throughout Europe (from Scotland to the Peloponnese) and Iran (infraspecific variability about $0.5 \%$ ).

The Cretan specimens all belong to the form described as $S$. cretensis Konow, 1887, which was regarded as an allopatric local population of $S$. multifasciata by Naito (1996) and Blank (2002). Alternatively, Schedl (2011) treated $S$. cretensis as a distinct species. The Cretan specimens differ from mainland ones in a number of characters:

- Postocellar area with sculpture similar to that of adjoining parts of the temples: punctures on postocellar area about as large as those on temples, with shiny unsculptured interspaces (Fig. 20). Terga 3-9 and all sterna entirely yellow (Fig. 21). Female metatibia basally white with apical two-thirds black; coxa mainly yellow. S. cretensis

- Postocellar area with denser sculpture than on adjoining parts of temples: average puncture diameter on postocellar area smaller than on temples, with interspaces matt (Fig. 22). Terga $2-8$ in female mainly black, with pale apical margin (Fig. 23); male often with several terga black-marked. Female metatibia basally white with apical two-thirds red-brown; coxa entirely black S. multifasciata

Further studies, including sequencing of nuclear genes, are required to clarify the status of the Cretan taxon.

\section{Cephidae}

\section{Calameuta haemorrhoidalis (Fabricius, 1781)}

Material. Crete; $7 q \propto+, 1 \hat{\jmath}$, Nea Roumata, 21.iv.2013. 1ठ, Fournes-Meskla, 22.iv.2013. 1§̄, Drakona, 22.iv.2013. 1ð, Drakona 2, 22.iv.2013. 1 , Askifou, 23.iv.2013. 1 ,

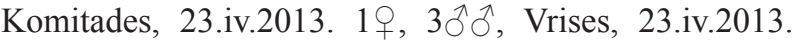
1 , , Kakopetros, 24.iv.2013. 1ð, Kandanos, 24.iv.2013. $2 \widehat{\jmath}$, Platanias, 24.iv.2013. 19, Strovles, 24.iv.2013. 1 ,
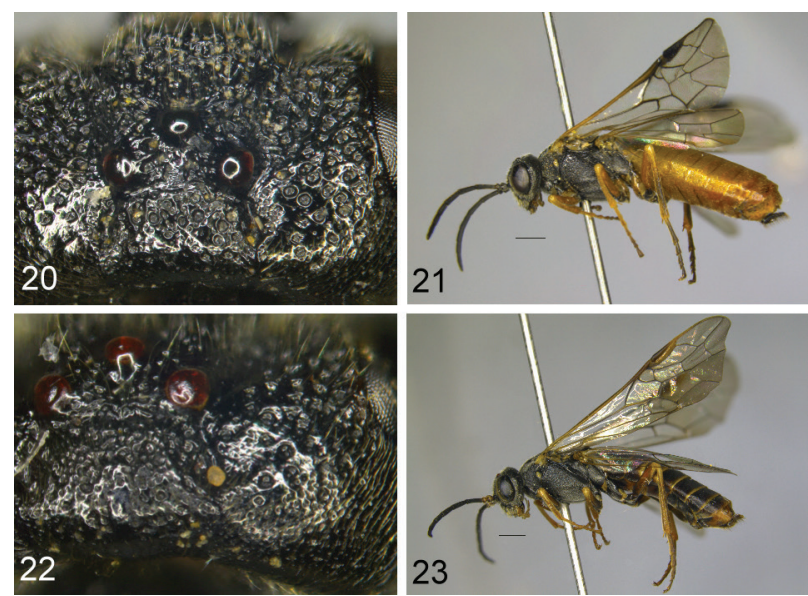

Figures 20-23. Strongylogaster multifasciata, + . 20, head, Crete. 21, habitus lateral, Crete, scale $=1 \mathrm{~mm}$. 22, head, Scotland. 23, habitus lateral, Scotland, scale $=1 \mathrm{~mm}$.

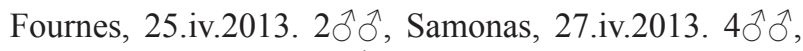
Agia Irini, 28.iv.2013. 1ð, Topolia, 29.iv.2013. 1ㅇ, Lousakies, 29.iv.2013.

\section{Calameuta idolon (Rossi, 1794)}

Material. Crete; 1§, Krasi, 28.iii.2013. 1옹 Samonas, 27.iv.2013. $2 \hat{\jmath}$, Lousakies, 29.iv.2013. 1ð, Topolia, 29.iv. 2013.

\section{*†Phylloecus faunus Newman, 1838}

Material. Crete; 1 , , Fournes-Meskla, 22.iv.2013.

A remarkable species because of its thelytoky, unusual in the Cephidae, and its mainly southern European distribution which extends north along the Atlantic coast to the French Department of the Manche (Chevin 1993; as Hartigia albomaculata), and possibly, at least historically, into southern England (Liston and Prous 2014).

\section{${ }^{\dagger}$ Trachelus tabidus (Fabricius, 1775)}

Material. Crete; $7 \uparrow q, 1 \hat{\jmath}$, Moni, 28.iv.2013.

\section{Discussion}

\section{Affinities of the Cretan sawfly fauna}

Turrisi (2011) compared the richness and diversity of the sawfly fauna of the larger Mediterranean islands and pointed out that the fauna of Crete is most similar to that of Cyprus. This is hardly surprising, given that these are the two most easterly of the large islands, are at nearly the same latitude, share similar climatic conditions, and are roughly equal in size (Crete $8336 \mathrm{~km}^{2}$; Cyprus 9251 $\mathrm{km}^{2}$ ). Furthermore, a shared history of massive alteration of the natural vegetation by human activity, continued 
over many thousands of years, has created similar habitats in both. Sometimes the resulting niches are occupied by the same sawfly species. These are species that occur, probably in many cases naturally, widely in the Mediterranean region (e.g. Calameuta idolon), or are attached to plants that have a long history of cultivation (Hoplocampa brevis and Pristiphora abbreviata on pear [Pyrus]) and/ or were used as raw material for woven artefacts (Euura atra and E. proxima on Salix alba), a branch of technology already in use by c. 25000-22000 BCE (Soffer et al. 2000). Particularly sawflies that feed on plants important to humans can be suspected to have been introduced to regions outside their native ranges by human activity. Seaborne trade across the eastern Mediterranean is evident by Crete's Old Palace Period (c. 2000-1600 BCE), and Crete and Cyprus were important trade centres in the later 2nd millenium BCE (Wardle 1997, Pulak 1998). The use of common plants from the eastern Mediterranean shoreline as dunnage, or packing material, on ships of this period (Bass et al. 1967; Pulak 1998) represents another potential means of human-induced colonisation, involving sawfly species attached to plants which have no obvious direct use to humans. Long before recognisable trade patterns became evident, colonisation by humans using boats occurred, and the colonists can be assumed to have brought quantities of plant-derived material with them. It is therefore likely that some species of sawflies were already accidentally introduced to Crete and Cyprus long ago. Neither should the possibility be overlooked, that sawfly species may also have been transported in the other direction, but in general one would expect intraspecific genetic divergence between introduced island populations and populations in their area of origin to be less than between populations which are naturally present in Crete and their mainland counterparts, providing that in the latter case the populations have long been effectively isolated from each other. Unfortunately, we do not yet have sufficient genetic data to test this. The introduction of species to areas outside their natural range leads to homogenisation of faunas, obscuring biogeographic patterns (Poulakakis et al. 2014).

In contrast to the examples mentioned above, in rather more cases sawfly species of the same genera which feed on the same or closely related hosts belong to different species on each island. Examples are: on Quercus in Crete Mesoneura opaca, Pristiphora parnasia, Periclista cretica and possibly Chevinia mediterranea / on Quercus in Cyprus Mesoneura lanigera Benson, 1954, Pristiphora calliprina Liston \& Jacobs, 2012 and Periclista rufiventris Zombori, 1979. On Acer in Crete Heterarthrus imbrosensis, Pristiphora cretica, Pristiphora sp. [subbifi$d a$ group] and P. tetrica / on Acer in Cyprus Heterarthrus cypricus Schedl, 2005 and Pristiphora schedli Liston \& Späth, 2008. We consider that these groups of species are assemblages which are naturally present on each island and that they illustrate a profound dissimilarity of their sawfly faunas, when these are compared at species level. On the other hand, six of the eight species mentioned above from Crete also occur in mainland Greece.

\section{Age of the Cretan sawfly fauna: influenced by a high rate of extinction?}

Both Crete and Cyprus have been separated from continental landmasses for at least 5 million years, and their degree of isolation since has sometimes been stated to be similar to that of today (Akin et al. 2010), although Ebmer (2014) drew attention to now vanished and still existing islands that could have functioned or might still function as "stepping stones" for winged insects to reach Crete. Poulakakis et al. (2014) reviewed the current state of knowledge of the phylogeography of animal taxa in the Aegean and surrounding areas and recognised four main patterns of colonisation. The first of these includes species present before the formation of the mid-Aegean Trench, more than 9 million years ago. The comparatively low degree of genetic divergence between mainland and island sawfly populations of the same or similar [morpho-] species, suggests that even the earliest species to have become established on Crete and Cyprus as part of the modern fauna arrived there considerably later than this, and probably even after the Messinian Salinity Crisis, 5-6 million years ago. That apparently no sawflies now use the Tertiary relict, endemic Cretan tree Zelkova abelicea as a host, is weakly indicative of a possible loss through extinction of ancient members of the Cretan sawfly fauna. Possibly much more important in its impact on the sawfly fauna was the change to the Mediterranean climate around 3.2 Ma (Fernández-Mazuecos and Vargas 2010).

Several other more recent events have at times been considered to be linked to a high rate of extinction in the Cretan flora and fauna, including for example the establishment of Neolithic culture 8400-7500 BP and the eruption of Santorini at around 3600 BP (Bottema and Sarpaki 2003). Recent studies do not support the hypothesis that the flora of Crete was devastated by ash deposition after the Santorini eruption (Bottema and Sarpaki 2003). On the contrary, a tendency noticeable in many recent works (e.g. Poulakakis et al. 2014) is to ascribe greater importance than previously to the shaping of the modern fauna and flora of Crete by human activities compared with natural events.

\section{Cretan endemics}

In many cases it is still impossible to state categorically whether a particular sawfly species is endemic to a Mediterranean island. This problem was discussed by Liston and Jacobs (2012) with reference to Cyprus. Pristiphora cretica, previously recorded only from Crete, is now known also to occur on the Greek mainland. Species which are probably endemic to Crete are Allantus nigrolinearis, Aneugmenus oertzeni, Periclista cretica and Pristiphora sp. [subbifida group]. The taxonomic status of Heterarthrus imbrosensis and Strongylogaster cretensis is equivocal: they could either be island endemic species, or are conspecific with taxa in mainland Europe. The Cretan sawfly fauna thus contains a higher proportion of endemic species than any other Mediterranean island, al- 
though the number of endemics in Sicily, which has not been intensively investigated, may prove to be greater because the fauna is much richer (Turrisi 2011, Liston and Jacobs 2012, Liston et al. 2013). It is noteworthy that none of the single island endemic sawfly species known from the Mediterranean has so far been shown to have a single island endemic plant species as its larval host. On the contrary, for those of the endemic sawflies with known hosts, the plant species involved are rather widespread in the Mediterranean (e.g. Pteridium aquilinum, Quercus coccifera, Acer sempervirens) and the biology of the sawfly seems very similar to related mainland taxa. We suggest that this may be because most such sawflies are neoendemics, i.e. speciation has largely been driven by random genetic drift after isolation, rather than adaptive differentiation. If so, this situation contrasts strongly with that found in vascular plants. The endemic flora of Crete, comprising about $10 \%$ of the total, has a strongly relict character, although containing a not inconsiderable neoendemic element (Georghiou and Delepetrou 2010).

\section{Niche specialisation of sawflies within the same plant host species}

Three species of Pristiphora belonging to the same species group occur in Crete on the same host (Acer sempervirens) and partly at the same localities. It is remarkable that adults of two of these species were found on individual trees at different stages of vegetative development: $P$. tetrica on plants at a less advanced stage than those frequented by $P$. cretica. It would be interesting to know if the third species, Pristiphora sp. [subbifida group], also differs in this habit. Although a few examples of differing phenology between closely related species on the same host are known in other Tenthredinidae (e.g. Parna apicalis (Brischke, 1888) and $P$. tenella (Klug, 1816): leaf-miners on Tilia), P. cretica and $P$. tetrica are exceptional in that their adults can be found at the same locality on the same day, but on different trees. This is made possible by the very large variability in vegetative phenology of the host. Although the larva of P. cretica remains unknown, larvae of other species in the subbifida group are similar in appearance and behaviour: cryptically coloured, solitary, leaf-edge feeders. The rather low abundance of adults at any site, the small size of individuals, the [probably] solitary habits of the larvae and the abundance of the food resource (leaves) lead us to suppose that competition between the larvae of these species is negligible. It would be very interesting to know more about the apparently differing behavioural strategies of the Cretan Acer-feeding Pristiphora.

\section{Conclusions}

The quantitative similarity between the sawfly faunas of Crete and Cyprus identified by Turrisi (2011) still holds, with 42 species now known in Crete and 43 in Cyprus (Liston and Jacobs 2012), but the recent investigations on Cypriot sawflies and the present study on Crete revealed that the faunas are qualitatively more dissimilar than previously supposed, at least when compared at species level. The majority of characteristic species in Cyprus have an exclusively eastern Mediterranean distribution, that only extends in two cases (Empria archangelskii, Mocsarya syriaca Benson, 1936) as far West as Crete. Many more species are shared between the fauna of Crete and mainland Greece, than between the two islands.

Although the Cretan sawfly fauna is species poor, it is valuable and worthy of conservation not only because of its proportionately high number of endemic species and genetically distinctive populations, but also because of those which are elsewhere known only from the southern Balkan peninsula (Pristiphora cretica), or are isolated populations on the western edge of the species range (Empria archangelskii, Mocsarya syriaca).

\section{Acknowledgements}

Dr Manfred Kraus, Dr Stefan Schmidt, Dr Olga Schmidt (Zoologische Staatssammlung, Munich), Dr Stephan M. Blank, Dr Andreas Taeger (SDEI) and the staff of the Barcoding of Life Data System (University of Guelph, Ontario, Canada) helped us to obtain barcode sequences of some specimens. Dr Frank Koch (Museum für Naturkunde, Berlin), Mr Henri Savina (Toulouse), Prof. Dr Wolfgang Schedl (Innsbruck), Mrs Lisa Standfuss, Prof. Dr Klaus Standfuss (Dortmund), Mr Matti Viitasaari (Helsinki) and Prof. Dr Meicai Wei (Changsha) made specimens available for examination. Mrs Gillian Galway drew our attention to literature which mentions the transport of plant material in the ancient eastern Mediterranean. Dr Akihiko Shinohara (Tokyo) and Dr Veli Vikberg (Turenki) reviewed the manuscript and suggested improvements. We are grateful to the Museum für Naturkunde, Berlin, for enabling open access publication of this work.

\section{References}

Akin C, Bilgin CC, Beerli P, Westaway R, Ohst T, Litvinchuk SN, Uzzell T, Bilgin M, Hotz H, Guex G-D, Plötner J (2010) Phylogeographic patterns of genetic diversity in eastern Mediterranean water frogs have been determined by geological processes and climate change in the Late Cenozoic. Journal of Biogeography 37(11): 2111-2124. doi: 10.1111/j.1365-2699.2010.02368.x

Bass GF, Throckmorton P, Du Plat Taylor J, Hennessy JB, Shulman AR, Buchholz H-G (1967) Cape Gelidonya: A Bronze Age Shipwreck. Transactions of the American Philosophical Society 57(8): 1-177. doi: $10.2307 / 1005978$

Benson RB (1968) Hymenoptera from Turkey Symphyta. Bulletin of the British Museum (Natural History). Entomology series 22(4): 111-207.

Blank SM (1996) Revision of the sawflies described by Lothar Zirngiebl. (Preliminary studies for a catalogue of Symphyta, part 2.) (Insecta, Hymenoptera, Symphyta). Spixiana 19(2): 195-219.

Blank SM (1998) Die mittel- und nordeuropäischen Selandriinae (Hymenoptera: Tenthredinidae). In: Taeger A, Blank SM (Eds) 
Pflanzenwespen Deutschlands (Hymenoptera, Symphyta). Kommentierte Bestandsaufnahme. Goecke and Evers, Keltern, 207-224.

Blank SM (2002) Taxonomic Notes on Strongylogasterini (Hymenoptera: Tenthredinidae). Proceedings of the entomological Society of Washington 104(3): 692-701.

Bottema S, Sarpaki A (2003) Environmental change in Crete: a 9000-year record of Holocene vegetation history and the effect of the Santorini eruption. The Holocene 13(5): 733-749. doi: 10.1191/0959683603hl659rp

Brischke CGA (1883) Beobachtungen über die Arten der Blatt- und Holzwespen von C. G. A. Brischke, Hauptlehrer a.D. in Langfuhr und Dr. Gustav Zaddach Professor in Königsberg, mitgeteilt von Brischke aus Zaddach's Manuscripten. Schriften der physikalisch-ökonomischen Gesellschaft zu Königsberg 23[1882]: 127-200; Tafel I (7).

Brullé A (1832) Zoologie. Deuxième Section. Des animaux articulés. Expédition scientifique de Morée. Section des sciences physiques, Paris, F. G. Levrault, Strasbourg 3(1): 64-395; Fol. 1-29.

Chevin H (1993) Hartigia albomaculata (Stein) espèce souvent confondue avec Hartigia nigra (Harris) (Hymenoptera, Cephidae). L'Entomologiste. Revue d'Amateurs 49(6): 273-276.

Ebmer AW (2014) Die nicht-parasitische Halictidae der Insel Zypern im Vergleich zu Kreta mit einer Monographie der Lasioglossum bimaculatum-Artengruppe und einer Übersicht der Halictus nicosiae-Untergruppe (Insecta: Hymenoptera: Apoidea: Halictidae). Linzer biologische Beiträge 46(1): 291-413.

Fernández-Mazuecos M, Vargas P (2010) Ecological rather than geographical isolation dominates Quaternary formation of Mediterranean Cistus species. Molecular Ecology 19: 1381-1395. doi: 10.1111/j.1365-294X.2010.04549.x

Georghiou K, Delepetrou P (2010) Patterns and traits of the endemic plants of Greece. Botanical Journal of the Linnean Society 162: 130-422. doi: 10.1111/j.1095-8339.2010.01025.x

Greathead DJ (1978) The larvae and notes on the life history of Corynis similis (Mocsary) (Hymenoptera: Cimbicidae). Journal of Natural History, an International Journal of Taxonomic and General Biology 12(1): 107-111.

Haris A (2004) New sawflies from Spain (Hymenoptera, Tenthredinidae). Graellsia 60 (2): 163-165. doi: 10.3989/graellsia.2004.v60.i2.211

Hebert PDN, Stoeckle MY, Zemlak TS, Francis CM (2004) Identification of birds through DNA barcodes. PLoS Biology 2: 1657-1663. doi: 10.1371/journal.pbio.0020312

ICZN (1999) International Code of Zoological Nomenclature. Fourth Edition. London, 1-306.

Jacobs H-J, Taeger A, Blank SM (in preparation) Corynis (Hymenoptera, Cimbicidae, Corynidinae): identification and distribution of the dwarf cimbicids.

Knight GT (2006) First British Records of the Sawfly Emphytus laticinctus (Serville) (Hymenoptera: Tenthredinidae). British journal of entomology and natural history 19: 193-198.

Koch F (1988) Zur Differentialdiagnose einiger Allantus-Arten (Insecta, Hymenoptera, Symphyta: Tenthredinidae). Reichenbachia, Staatliches Museum für Tierkunde Dresden 26(9): 43-53.

Konow FW (1887) Neue griechische und einige andere Blattwespen. Wiener entomologische Zeitung 6(1): 19-28.

Konow FW (1905) Hymenoptera. Fam. Tenthredinidae. Genera Insectorum 29: 1-176.

Kozlowski G, Frey D, Fazan L, Egli B, Bétrisey S, Gratzfeld J, Garfi G, Pirintsos S (2013) The Tertiary relict tree Zelkova abelicea (U1- maceae): distribution, population structure and conservation status on Crete. Oryx 48(1): 80-87. doi:10.1017/S0030605312001275

Lacourt J (1976) Description du male de Pristiphora tetrica [Hym, Tenthredinidae]. L'Entomologiste. Revue d'Amateurs 32(3): $143-144$.

Lacourt J (1977) Note sur les Dolerus du Maroc (Hym. Tenthredinidae). Bulletin de la Société Entomologique de France 82: 25-29.

Lacourt J (1999) Répertoire des Tenthredinidae ouest-paléarctiques (Hymenoptera, Symphyta). Mémoires de la Société Entomologique de France 3: 1-432.

Lacourt J (2003) Refléxions sur la classification des Blennocampinae, avec description d'un nouveau genre et d'une nouvelle espèce du sud de la France et de Corse (Hymenoptera, Tenthredinidae). Bulletin de la Société Entomologique de France 108(5): 495-529.

Legakis A, Kypriotakis Z (1994) A biogeographical analysis of the island of Crete, Greece. Journal of Biogeography 21: 441-445. doi: $10.2307 / 2845761$

Leppänen S, Altenhofer E, Liston AD, Nyman T (2012) Phylogenetics and evolution of host-plant use in leaf-mining sawflies (Hymenoptera: Tenthredinidae: Heterarthrinae). Molecular Phylogenetics and Evolution 64: 331-341.

Liston AD (2012) On West Palaearctic Mesoneura species (Hymenoptera: Tenthredinidae). The Entomologist's Monthly Magazine 148(3): 187-194.

Liston AD, Jacobs H-J (2012) Review of the sawfly fauna of Cyprus, with descriptions of two new species (Hymenoptera, Symphyta). Zoology in the Middle East 56: 67-84. doi: 10.1080/09397140.2012.10648943

Liston AD, Jacobs H-J, Turrisi GF (2013) New data on the sawfly fauna of Sicily (Hymenoptera, Symphyta: Xyeloidea, Tenthredinoidea, Pamphilioidea, Cephoidea, Orussoidea). The Entomologist's Monthly Magazine 149(1): 29-65.

Liston AD, Prous M (2014) Sawfly taxa (Hymenoptera, Symphyta) described by Edward Newman and Charles Healy. Zookeys 398: 83-98. doi: 10.3897/zookeys.398.6595

Liston AD, Späth J (2008) On the sawflies of Cyprus, with a revision of the Pristiphora subbifida species group (Hymenoptera, Symphyta). Mitteilungen der Münchner Entomologischen Gesellschaft 98: 99-120.

Liston AD, Zerafa M (2012) The Sawflies of the Maltese Islands (Hymenoptera, Symphyta). Bulletin of the Entomological Society of Malta 5: 49-55.

Malm T, Nyman T (2015) Phylogeny of the symphytan grade of Hymenoptera: new pieces into the old jigsaw(fly) puzzle. Cladistics 31: 1-17. doi: 10.1111/cla.12069

Naito T (1996) Phylogeny of the fern associated sawfly genus Strongylogaster Dahlbom (Hymenoptera: Tenthredinidae). Memoirs of the Entomological Society of Washington 17: 161-178.

Niu G, Wei M (2013) Review of Aneugmenus Hartig (Hymenoptera: Tenthredinidae) with description of a new species from China and a key to world species (excluding Neotropical). Entomotaxonomia 35(3): 221-232.

Poulakakis N, Kapli P, Lymberakis P, Trichas A, Vardinoyiannis K, Sfenthourakis S, Mylonas M (2014) A review of phylogeographic analyses of animal taxa from the Aegean and surrounding regions. Journal of Zoological Systematics and Evolutionary Research 53(1): 18-32. doi: 10.1111/jzs.12071

Prous M (2012) Taxonomy and phylogeny of the sawfly genus Empria (Hymenoptera, Tenthredinidae). Dissertationes Biologicae Universitatis Tartuensis 222: 1-192. 
Pulak C (1998) The Uluburun shipwreck: an overview. The International Journal of Nautical Archaeology 27(3): 188-224. doi: 10.1111/ j.1095-9270.1998.tb00803.x

Prous M, Blank SM, Goulet H, Heibo E, Liston A, Malm T, Nyman T, Schmidt S, Smith DR, Vardal H, Viitasaari M, Vikberg V, Taeger A (2014) The genera of Nematinae (Hymenoptera, Tenthredinidae). Journal of Hymenoptera Research 40: 1-69. doi: 10.3897/ JHR.40.7442

Ratnasingham S, Hebert PDN (2007) BOLD: The barcode of Life data System (www.barcodinglife.org). Molecular Ecology Notes 7: 355364. doi: 10.1111/j.1471-8286.2007.01678.x

Savina H, Chevin H, Liston A (2014) Hyménoptères Symphytes nouveaux ou rares pour les départements de l'Ariège et de la Haute-Garonne:premier complément aux listes préliminaires. Bulletin de la Société Entomologique de France 119(4): 481-486.

Schedl W (1981) Die Pflanzenwespen der Insel Kreta (Insecta: Hymenoptera, Symphyta). Berichte des Naturwissenschaftlich-Medizinischen Vereins in Innsbruck 68: 145-157.

Schedl W (1985) Bemerkenswerte Nachweise von Pflanzenwespen aus der Mediterraneis (Insecta: Hymenoptera, Symphyta). Berichte des Naturwissenschaftlich-Medizinischen Vereins in Innsbruck 72: 189-198.

Schedl W (1993) Sawflies sensu lato of the Island of Crete (Insecta: Hymenoptera, Symphyta). Biologia Gallo-Hellenica 20(1): 169-176.

Schedl W (2011) Überblick über die Arten-Diversität der Pflanzenwespen der griechischen Insel Kreta (Insecta: Hymenoptera: Symphyta). Linzer biologische Beiträge 43(2): 1259-1267.

Smith DR (2003) Expanding Ranges for Four Species of Invasive Sawflies (Hymenoptera: Tenthredinidae) in Eastern United States. Proceedings of the entomological Society of Washington 105(1) 246-248.

Soffer O, Adovosio JM, Hyland DC (2000) The 'Venus' Figurines: Textiles, Basketry, Gender and Status in the Upper Palaeolithic. Current Anthropology 41(4): 511-537. doi: 10.1086/317381

Standfuss K, Liston AD, Standfuss L, Jansen E (2010) Sawflies (Hymenoptera, Symphyta) of the southern Magnisía Peninsula, Thessaly, Greece. Entomofauna. Zeitschrift für Entomologie 31(13): 153-168.

Taeger A, Altenhofer E, Blank SM, Jansen E, Kraus M, Pschorn-Walcher H, Ritzau C (1998) Kommentare zur Biologie, Verbreitung und Gefährdung der Pflanzenwespen Deutschlands (Hymenoptera, Symphyta). In: Taeger A, Blank SM (Eds) Pflanzenwespen Deutschlands (Hymenoptera, Symphyta). Kommentierte Bestandsaufnahme. Goecke and Evers, Keltern, 49-135.

Taeger A, Blank SM, Liston AD (2010) World Catalog of Symphyta (Hymenoptera). Zootaxa 2580: 1-1064.

Turrisi GF (2011) Diversity and biogeographical remarks on "Symphyta" of Sicily (Hymenoptera). Biogeographia 30: 511-528.

Wardle KA (1997) The Palace Civilizations of Minoan Crete and Mycenaean Greece 2000-1200 BC. In: Cunliffe B (Ed.) The Oxford Illustrated History of Prehistoric Europe. Oxford University Press, Oxford, 202-243.

Zirngiebl L (1937) Beitrag zur Biologie des Emphytus Klg. (Allantus Pz. u. Jur.) balteatus Klg. und Beschreibung des unbekannten Männchens. Festschrift zum 60. Geburtstage von Professor Dr. Embrik Strand 2: 638-647.

\section{Appendix}

\section{Checklist of the Symphyta of Crete}

\section{Xyelidae}

Xyela graeca (J. Stein, 1876)

\section{Cephidae}

Cephus pygmeus (Linnaeus, 1767)

Calameuta haemorrhoidalis (Fabricius, 1781)

Calameuta idolon (Rossi, 1794)

Phylloecus faunus Newman, 1838

Trachelus tabidus (Fabricius, 1775)

Trachelus troglodyta (Fabricius, 1787)

\section{Argidae}

Arge melanochra (Gmelin, 1790)

Arge ochropus (Gmelin, 1790)

Arge scita (Mocsáry, 1880)

\section{Cimbicidae}

Corynis krueperi (J. Stein, 1876)

\section{Tenthredinidae}

\section{Allantinae}

Allantus nigrolinearis (Zirngiebl, 1937)

Allantus viennensis (Schrank, 1781)

Ametastegia glabrata (Fallén, 1808)

Athalia ancilla Serville, 1823

Athalia circularis (Klug, 1815)

Athalia cordata Serville, 1823

Athalia rosae (Linnaeus, 1758)

Empria archangelskii Dovnar-Zapolskij, 1929

\section{Blennocampinae}

Chevinia mediterranea Lacourt, 2003

Heterarthrus imbrosensis Schedl, 1981

Periclista cretica (Schedl, 1981)

Silliana lhommei (Hering, 1934)

Halidamia affinis (Fallén, 1807)

Nematinae

Cladius ordubadensis Konow, 1892

Cladius pectinicornis (Geoffroy, 1785)

Hoplocampa brevis (Klug, 1816)

Hoplocampa chrysorrhoea (Klug, 1816)

Mesoneura opaca (Fabricius, 1775)

Euura atra (Jurine, 1807)

Euura proxima (Serville, 1823)

Pristiphora abbreviata (Hartig, 1837)

Pristiphora cretica Schedl, 1981

Pristiphora pallidiventris (Fallén, 1808)

Pristiphora parnasia Konow, 1902

Pristiphora sp. [subbifida group]

Pristiphora tetrica (Zaddach, 1883)

\section{Selandriinae}

Aneugmenus oertzeni (Konow, 1887)

Dolerus puncticollis Thomson, 1871

Strongylogaster multifasciata (Geoffroy, 1785)

\section{Orussidae}

Mocsarya syriaca Benson, 1936

Orussus morio Guiglia, 1954 